\title{
What is the Real Impact of SARS-CoV-2 on Stroke: Do We More Have to Learn?
}

\section{Luiz Severo Bem Junior ${ }^{1,2 *}$, Luís Felipe Gonçalves de Lima², Júlio Cesár Tavares Marques², Pedro Lukas do Rêgo Aquino ${ }^{3}$, Andrey Maia Silva Diniz ${ }^{4}$, Artêmio José Araruna Dias ${ }^{2}$, Flávio Monteiro de Oliveira Júnior ${ }^{5}$, Nicollas Nunes Rabelo ${ }^{6,7}$, Hildo Rocha Cirne de Azevedo Filho ${ }^{1}$}

${ }^{1}$ Neuroscience Post-Graduate Program, Federal University of Pernambuco, Recife, Brazil

${ }^{2}$ Faculty of Medical Science, UNIFACISA, Campina Grande, Brazil

${ }^{3}$ Faculty of Medical Science, University of Pernambuco, Recife, Brazil

${ }^{4}$ Faculty of Medical Science, Federal University of Paraiba, João Pessoa, Brazil

${ }^{5}$ Neurosurgical Intensive Care Unit, Hospital da Restauração, Recife, Brazil

${ }^{6}$ Neurosurgery Department, University of São Paulo, São Paulo, Brazil

${ }^{7}$ Neurosurgery Department, UniAtenas University Center, Paracatu, Brazil

*Corresponding author: Luiz Severo Bem Junior, Neuroscience Post-Graduate Program, Federal University of Pernambuco, Recife/Pernambuco, Brazil, Tel: +55-81-998248201

\begin{abstract}
Background and Purpose: Coronaviruses (CoV) is virus infectious disease witch a considerable spectrum of clinical presentation. Neurologic symptoms related to SARS-CoV-2 have been described recently in the literature. Among a wide variety of neurological symptoms, acute cerebrovascular disease is one of the most serious complications. This review aimed to reveal the current knowledge regarding stroke in new coronavirus infection as way to improve its diagnosis and treatments.

Methods: A systematic literature review was carried out to identify the particularities of SARS-CoV-2 in patients with stroke. An electronic search of the literature was conducted in the PubMed database between December first, 2019, and June 11, 2020. A total of 693 articles were extracted. We included articles in all languages. Were excluded conference papers, reviews, published letters, and editorials.

Results: Out of the 693 screened articles, 39 were selected for full-text review. Were excluded 29 studies because they did not report stroke in COVID-19 patients. Thus, 10 papers were included in this review with total of 22 patients.

Conclusion: There is strong evidence that vascular complications may arise for the most part due to the well-recognized potentially fatal inflammatory storm, which reflects a hyperactivation of inflammatory factors and dysfunction of the coagulation system, especially D-dimer and platelet abnormalities.
\end{abstract}

What other variables can be associated to poor outcome of these patients?

\section{Keywords}

COVID-19, Neurological, SARS-CoV-2, Stroke, Systematic review

\section{Introduction}

Coronaviruses (CoVs) cause enteric and respiratory diseases in humans. These viruses are enveloped non-segmented RNA [1]. Severe acute respiratory syndrome coronavirus (SARS-CoV) and middle east respiratory syndrome coronavirus (MERS-CoV) had already been known in the literature $[2,3]$. However, another highly pathogenic coronavirus named SARS-CoV-2 emerged in December 2019 in China and reached the worldwide.

Symptoms ranged from asymptomatic infection, to severe pneumonia that may lead to acute respiratory syndrome and several clinical complications. The disease can manifest a wide variety of signs and symptoms, which affect the most diverse systems of the body. Respiratory involvement is the most common symptom in patients with SARS-CoV-2 infection, however, there

Citation: Junior LSB, Lima LFG, Marques JCT, Aquino PLR, Diniz AMS, et al. (2020) What is the Real Impact of SARS-CoV-2 on Stroke: Do We More Have to Learn?. Int J Neurol Neurother 7:103. doi. org/10.23937/2378-3001/1410103

Accepted: September 07, 2020: Published: September 09, 2020

Copyright: (C) 2020 Junior LSB, et al. This is an open-access article distributed under the terms of the Creative Commons Attribution License, which permits unrestricted use, distribution, and reproduction in any medium, provided the original author and source are credited. 


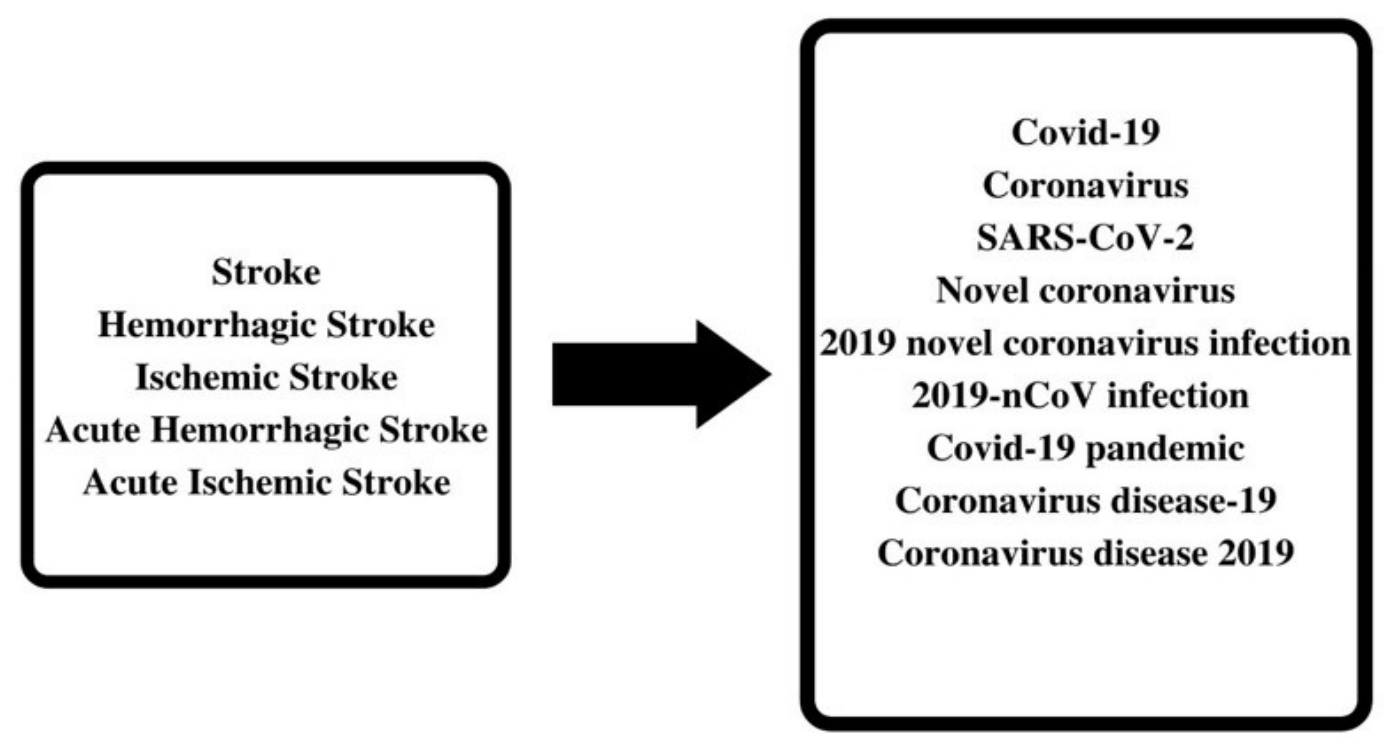

Figure 1: Schematic representation of the crossover of keywords.

are reports of neurological manifestations [1,2]. These clinical manifestations are seen, above all, in the moderate and severe forms of the disease. Neurological symptoms in COVID-19 include anosmia and hypogeusia, seizures, and strokes [4]. Among a wide variety of neurological symptoms, acute cerebrovascular disease is one of the most serious complications and affected $5.7 \%$ of patients in the study by Mao et al. [5]. This review aimed to reveal the current knowledge regarding stroke in new coronavirus infection as way to improve its diagnosis, treatment, and prognosis factors.

\section{Methods}

A systematic review of observational studies about COVID-19 in patients with stroke was carried out according to the recommendations of the Preferred Reporting Items for Systematic Reviews and Meta-Analyses (PRISMA) statement. An electronic search of the literature was conducted in the PubMed database between December first, 2019, and June 11, 2020. Data extraction and the evaluation of literature quality were conducted independently by two investigators, any disagreement was resolved by another investigator. The keywords used were "COVID-19", "Coronavirus", "SARS-CoV-2", "Novel coronavirus", "2019 novel coronavirus infection", "2019-nCoV infection", "COVID-19 pandemic", "Coronavirus disease-19", "Coronavirus disease 2019", "Stroke", "Hemorrhagic stroke", "Ischemic stroke", "Acute hemorrhagic stroke" and "Acute ischemic stroke". The Bolean operator "AND" was used to filter and select documents that were at the intersection of keywords. The descriptors were crossed in order to maximize the number of publications (Figure 1), so that all the words in the first square corssed with all the words in the second square.

A total of 693 articles were extracted. We included articles in all languages. Were excluded conference papers, reviews, published letters, and editorials? Our work is summarized in the diagram below (Figure 2).

\section{Results}

An initial search included as many as 693 articles. Out of the 693 screened articles, 39 were selected for full-text review. Were excluded 29 studies because they did not report stroke in COVID-19 patients. Thus, 10 papers were included in this review with total of 22 patients [6-15].

Within the group of 22 patients who, concurrently, had a stroke and COVID-19 event, 21 (95\%) patients had ischemic stroke at the arterial level and one patient had cerebral venous sinus thrombosis (4.5\%). The average age was 62.45 years, but $40 \%$ of patients were younger than 60 years, meaning it is not a uniform population. There was a tendency for ischemic brain events of large vessels to be in younger patients. Male was the most prevalent gender (68.2\%) [6-15].

In 20 patients (90.9\%), risk factors related to stroke pathology were reported. Hypertension was the most prevalent risk factor in the group, present in 14 patients $(63.6 \%)$, followed by diabetes $(27.3 \%)$, dyslipidemia (22.7\%), and cardiac disease in three individuals (13.6\%). Smoking patients, and patients with a history of stroke were also reported, $9.1 \%$ in each group. In addition, two patients had only high age as an isolated risk factor for stroke. In this sense, we realized that it is a group with a high prevalence of risk factors and the SARS-CoV-2 infection would be acting as a precipitating stroke in these patients [6-15].

Regarding the onset of stroke symptoms in the patients analyzed in relation to the onset of COVID-19 symptoms, a comparative date was concluded for 14 patients. Three patients (21.4\%) had a stroke episode before the symptoms of COVID-19 were noticed. 12 patients (one of them had an episode before and after the symptoms of COVID-19 appeared) had an episode 


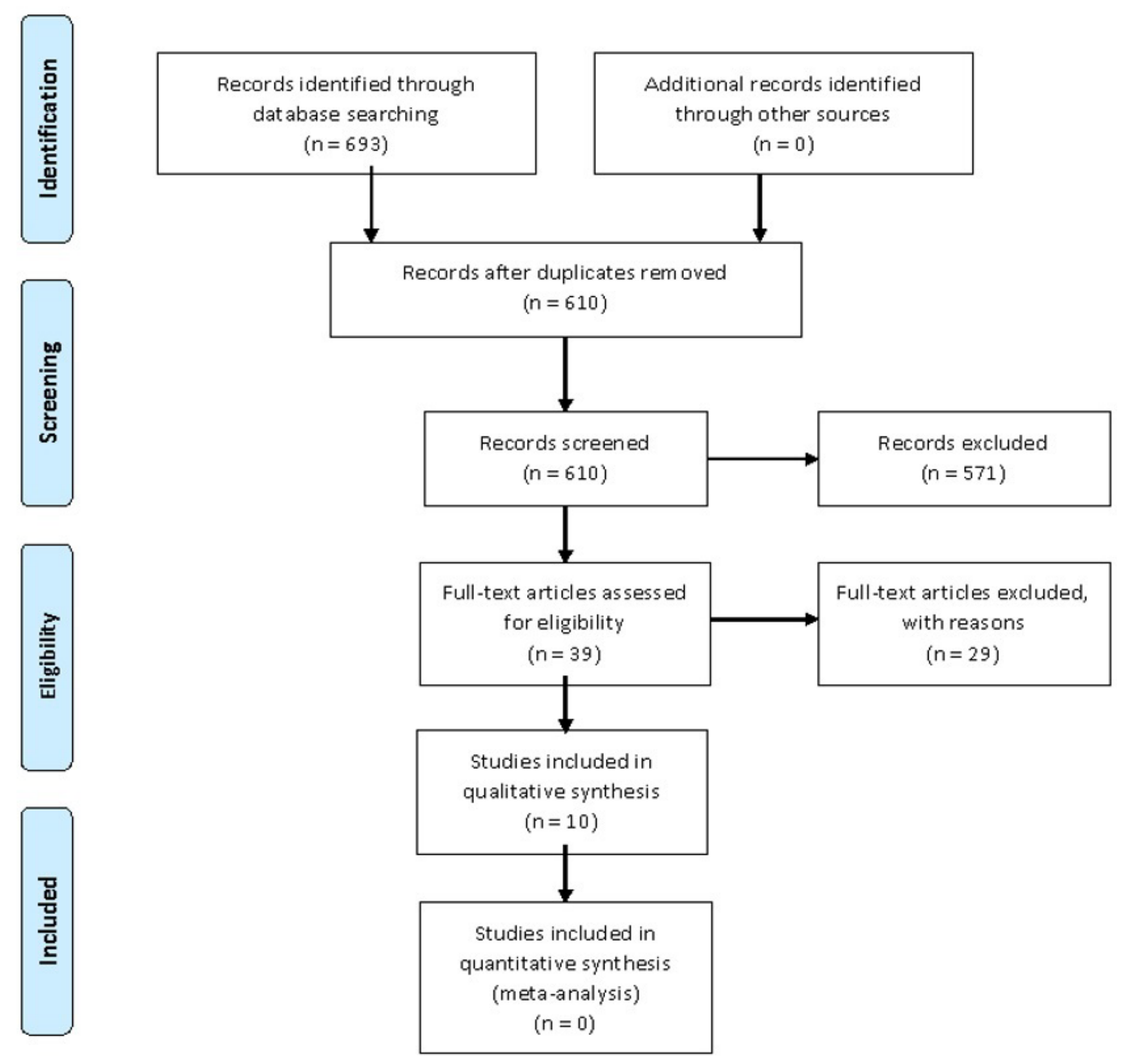

Figure 2: PRISMA flow diagram.

of stroke after the appearance of COVID-19. Of these 12 patients, seven $(58.3 \%)$ had the sudden episode in the first week and five (41.7\%) after the first week [6-15].

Regarding the characteristic of stroke in these patients and their laboratory tests, we found that in 20 patients $(90.2 \%)$ the stroke occurred at the level of large vessels and only two patients (9.1\%) were affected at the level of small vessels, demonstrating the great thrombotic factor that may have been influenced by the combination of risk factors and the pathophysiology of COVID-19. Regarding D-Dimer, it was checked in 19 patients and 16 (84.2\%) had high rates. This high prevalence of high rates of D-Dimer is compatible with the pathophysiology of stroke. The prothrombin time test was reported in 16 patients, being normal in ten patients (62.5\%) and elevated in six patients (37.5\%) [615]. Our analysis is summarized in Table 1.

\section{Discussion}

\section{Physiopathology}

COVID-19 involvement with thrombotic events: Significantly high levels of D-dimer and other fibrin degradation products have been increasingly correlated with poor prognosis in patients infected with SARS-CoV-2 [16]. Guan, et al. [17], in his study that analyzed the epidemic in the first 2 months in China, identified that 260 (46.4\%) of the 560 patients diagnosed with COVID-19 in the laboratory had elevated levels of D-dimer $(\geq 0.5$ $\mathrm{mg} / \mathrm{L}$ ), this elevation being more prominent in severe cases. Thus, high levels of fibrin degradation products have been increasingly correlated with poor outcomes in patients infected with SARS-CoV-2.

Due to these characteristics, many authors have reported that patients in this phase of the disease and 
Table 1: Acute vascular neurological manifestation in patients with SARV-CoV-2 infection.

\begin{tabular}{|c|c|c|c|c|c|c|c|c|}
\hline Study & Patients & Age & Gender & UD & D-dimer & $\begin{array}{l}\text { Type of } \\
\text { stroke }\end{array}$ & Treatment & Outcome \\
\hline $\begin{array}{l}\text { Avula, et al. } \\
\text { [6] }\end{array}$ & 4 & $81^{*}$ & $\begin{array}{l}75 \%, \mathrm{~F} \\
25 \%, \mathrm{M}\end{array}$ & $\begin{array}{l}\text { Hypertension: } \\
\text { 100\% } \\
\text { Dyslipdemia: } 75 \% \\
\text { Diabetes: } 25 \%\end{array}$ & $\begin{array}{l}\text { Elevated: } \\
50 \%\end{array}$ & IS & Aspirin & $75 \%$ died \\
\hline $\begin{array}{l}\text { Saiegh, et al. } \\
\text { [7] }\end{array}$ & 2 & $46.5^{*}$ & $\begin{array}{l}50 \%, \mathrm{~F} \\
50 \%, \mathrm{M}\end{array}$ & $\begin{array}{l}\text { None: } 50 \% \\
\text { ns: } 50 \%\end{array}$ & ns & $\begin{array}{l}\mathrm{IS} \\
\mathrm{ICH}\end{array}$ & $\begin{array}{l}\text { External ventricular } \\
\text { drain and } \\
\text { specific surgery }\end{array}$ & Survive \\
\hline $\begin{array}{l}\text { Beyrouti, et } \\
\text { al. [8] }\end{array}$ & 6 & $69.8^{*}$ & $\begin{array}{l}33.3 \%, F \\
66.6 \% \\
M\end{array}$ & $\begin{array}{l}\text { Hypertension: } \\
66.6 \%\end{array}$ & $\begin{array}{l}\text { Elevated: } \\
100 \%\end{array}$ & IS & $\begin{array}{l}\text { Anticoagulation: } 6.6 \% \\
\text { Intravenous } \\
\text { thrombolysis: } 16.6 \%\end{array}$ & $16.6 \%$ died \\
\hline $\begin{array}{l}\text { González- } \\
\text { Pinto, et al. [9] }\end{array}$ & 1 & 36 & $\mathrm{~F}$ & ns & Elevated & IS & $\begin{array}{l}\text { Supportive } \\
\text { Measures }\end{array}$ & Survive \\
\hline $\begin{array}{l}\text { Oxley, et al. } \\
{[10]}\end{array}$ & 5 & $40.4^{*}$ & $\begin{array}{l}20 \%, \mathrm{~F} \\
80 \%, \mathrm{M}\end{array}$ & $\begin{array}{l}\text { Hypertension: } 20 \% \\
\text { Dyslipdemia: } 20 \% \\
\text { Diabetes: } 40 \%\end{array}$ & $\begin{array}{l}\text { Elevated: } \\
60 \%\end{array}$ & IS & $\begin{array}{l}\text { Aspirin: } 60 \% \\
\text { Clot retrieval: } 80 \% \\
\text { Intravenous } \\
\text { thrombolysis: } 20 \% \\
\text { Anticoagulation: } 40 \%\end{array}$ & Survive \\
\hline $\begin{array}{l}\text { Moshayei, et } \\
\text { al. [11] }\end{array}$ & 1 & 80 & M & $\begin{array}{l}\text { Heart failure, } \\
\text { cardiovascular } \\
\text { shock, and } \\
\text { ischemic bilateral } \\
\text { lower limbs }\end{array}$ & ns & IS & $\begin{array}{l}\text { Supportive } \\
\text { measures }\end{array}$ & Survive \\
\hline $\begin{array}{l}\text { Hughes, et al. } \\
\text { [12] }\end{array}$ & 1 & 59 & $\mathrm{~F}$ & ns & ns & CVST & LMWH & Survive \\
\hline $\begin{array}{l}\text { Viguier, et al. } \\
\text { [13] }\end{array}$ & 1 & 73 & M & ns & Elevated & IS & LMWH & Survive \\
\hline $\begin{array}{l}\text { Tunç, et al. } \\
{[14]}\end{array}$ & 4 & $65.3^{*}$ & $\begin{array}{l}50 \% \mathrm{M} \\
50 \% \mathrm{~F}\end{array}$ & $\begin{array}{l}\text { Diabetes: } 25 \% \\
\text { Hypertension: } 75 \%\end{array}$ & $\begin{array}{l}\text { Elevated: } \\
75 \%\end{array}$ & IS & Antithrombotic therapy & Survive \\
\hline $\begin{array}{l}\text { Goldberg, et } \\
\text { al. [15] }\end{array}$ & 1 & 64 & M & $\begin{array}{l}\text { Hypertension, } \\
\text { aplastic anemia, } \\
\text { and splenectomy }\end{array}$ & Elevated & IS & ns & ns \\
\hline
\end{tabular}

"Median; F: female; M: male; y: years; UD: underlying disorders; IS: ischemic stroke; ICH: intracerebral hemorrhage; CVST: cerebral venous sinus thrombosis; ns: not specified; LMWH: low molecular weight heparin; D-dimer elevated levels: > $250 \mathrm{ng} / \mathrm{ml}$.

with this laboratory profile are in a state of hypercoagulability, which can also be associated with a worsening in the functioning of noble organs. For Spiezia, et al. [18], patients who have COVID-19 who are in this state of hypercoagulability due to hyperfibrinogenemia, which results in a greater formation of fibrin and polymerization, which can predispose to the appearance of thrombi.

Inflammatory responses by COVID-19: The cytokine storm consists of one of the main causes of acute respiratory distress syndrome (ARDS) and multiple-organ failure [19], which is an immunological phenomenon frequently seen in serious patients infected with SARSCoV-2. In a study evaluating the outcome of patients with persistent and high levels of inflammatory cytokines [20], it was concluded that the overproduction of pro-inflammatory cytokines such as tumor necrosis factor (TNF), IL-6 and IL-1B can cause up to death if high concentrations persist unabated over time.

In one of the first studies that addressed the topic, Huang, et al. [21] investigated the clinical findings and the cytokine profile of critically ill patients in Wuhan, suggesting that the cytokine storm may be associated with the severity of the disease. Another study that corroborates this reasoning argues that high levels of cytokines, specifically interleukin (IL) -2R and IL-6, in serum, can predict the severity of the disease and the prognosis of patients [22].

Renin cerebral angiontensin system in stroke pathogenesis: Another widely discussed issue is the affinity that the virus has for angiotensin-converting enzyme 2 (ACE2) receptors, which is a mechanism used to enter human cells. ACE2 receptor is determinate to viral tropism in host humans [23]. ACE2 is expressed in several tissues as such as airway epithelia, kidney cells, small in- 


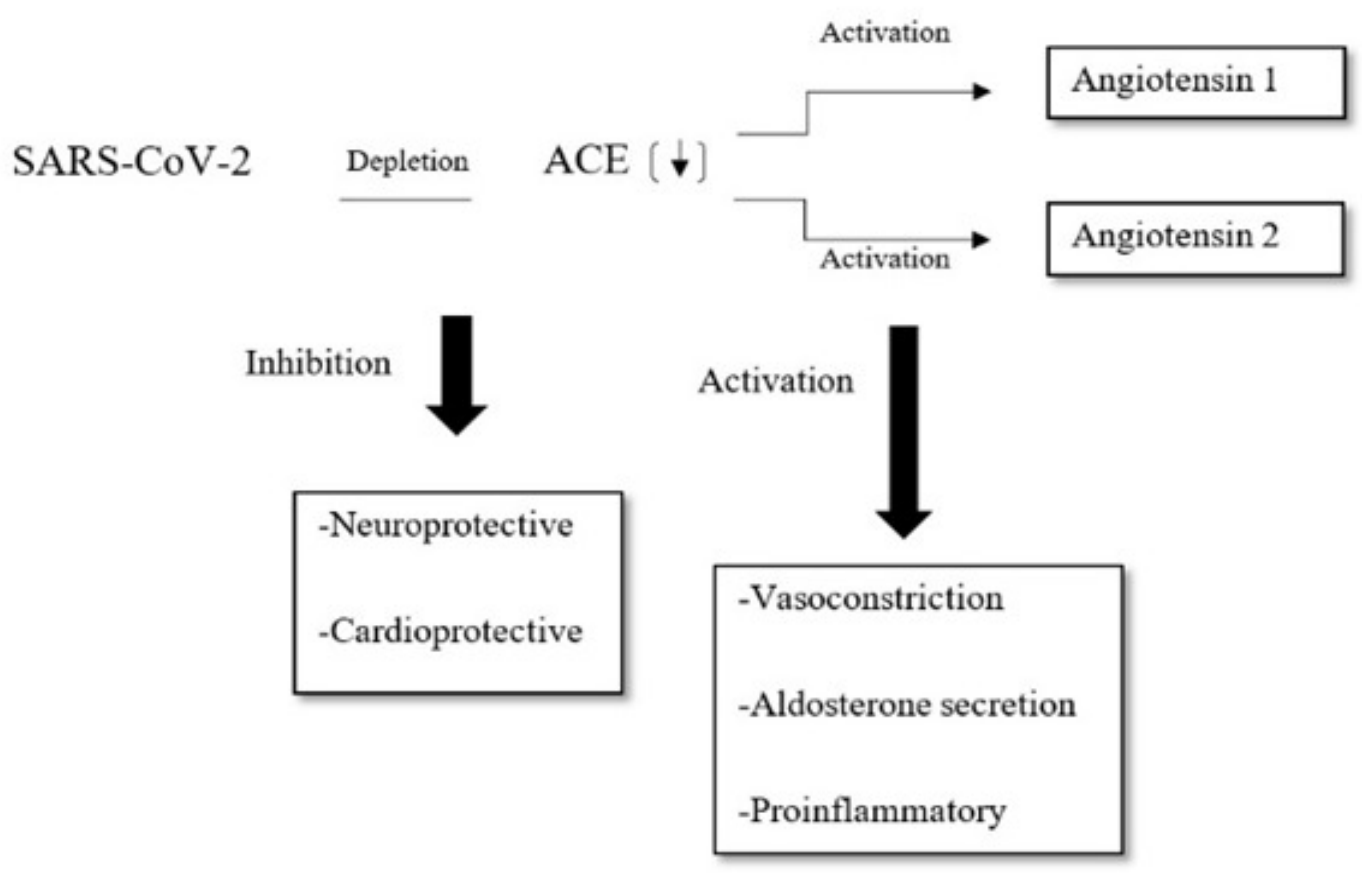

Figure 3: Pathophysiology of stroke predisposition in COVID-19. SARS-CoV-2 deplete ACE2 receptor and promote proinflammatory effect.

ACE2: Angiotensin-converting enzyme 2.

testine, lung parenchyma, and vascular endothelia and widely throughout the central nervous system [23,24]. The brain expresses ACE2 receptors at different sites, such as glial cells, neurons, astrocytes, and oligodendrocytes, this expression can cause these cells to become potential targets for SARS-CoV-2 [23,24]. However, ACE2 demonstrated a beneficial cardioprotective and neuroprotective actions $[23,24]$.

The SARS-CoV-2 virus binds to the ACE2 via its spike protein and transmembrane protein serine protease 2 (TMPRSS2) is also required for viral entry into cells [24]. TMPRSS2 active spike protein through proteolytic breakdown and SARS-CoV-2 can enter in the host cell [24]. The renin secreted from juxtaglomerular cells in the kidney cleaves angiotensinogen produced by the liver to angiotensin I, after that, angiotensin I is cleaved to angiotensin II. Angiotensin II promote vasoconstriction, aldosterone secretion, proinflammatory status, and procoagulation action. In addition, angiotensin II can worsen heart failure and pulmonary failure. ACE2 directly cleaves angiotensin I and angiotensin II to angiotensin (1-7) at the least stage [24]. Angiotensin (1-7) produces vasodilatation and has anti-inflammatory effects. Thus, the overexpression of ACE 2 in neuronal cells or endothelial progenitor cells promotes protective effect from inflammatory complication as ischemic stroke [24]. SARS-CoV-2 depletes ACE2 stock and predispose the host to develop stroke $[23,24]$. All of this information was summarized in Figure 3.

SARS-CoV-2 deplete ACE2 and worse endothelial function in organs as brain and heart $[23,24]$. This fact also explains the theory that SARS-CoV-2 action on
ACE2 predisposes mainly elder and male patients to develop stroke because this receptor is naturally decreased in this population $[23,24]$. Another point is that the COVID-19 promotes greater metabolic expenditure and this also predispose to stroke $[23,24]$.

\section{Treatment}

Currently, patients with ischemic stroke symptoms should be treated as suspected or possible to have SARS-CoV-2 infection. Reverse-transcription polymerase chain reaction test (RT-PCR) and CT-Chest can be necessary for all stroke patients to discard COVID-19 in pandemic era $[25,26]$. Stroke members team should wear appropriate personal protective equipment (PPE), including use a combination of surgical mask gloves, goggles or face shield, and gowns. Image investigation and blood investigation is crucial to understand the clinical status of the patient and should be performed as soon as available. Routine thromboprophylaxis is not recommended in ambulatory patients with respiratory symptoms or acute medical illness $[25,26]$. In the emergency room, patients diagnosed with ischemic stroke should receive the standard of stroke care and specific treatment with intravenous (IV) thrombolysis or mechanical thrombectomy is reserve to selected patients $[25,26]$. Our proposed management is summarized in Figure 4.

SARS-CoV-2 infected patients have a high hypercoagulability state due to elevated concentration of $C$ reactive protein and D-dimers in patients with SARSCoV-2 infection. Studies conducted in non SARS-CoV-2 infected acute ischemic stroke patients demonstrated 


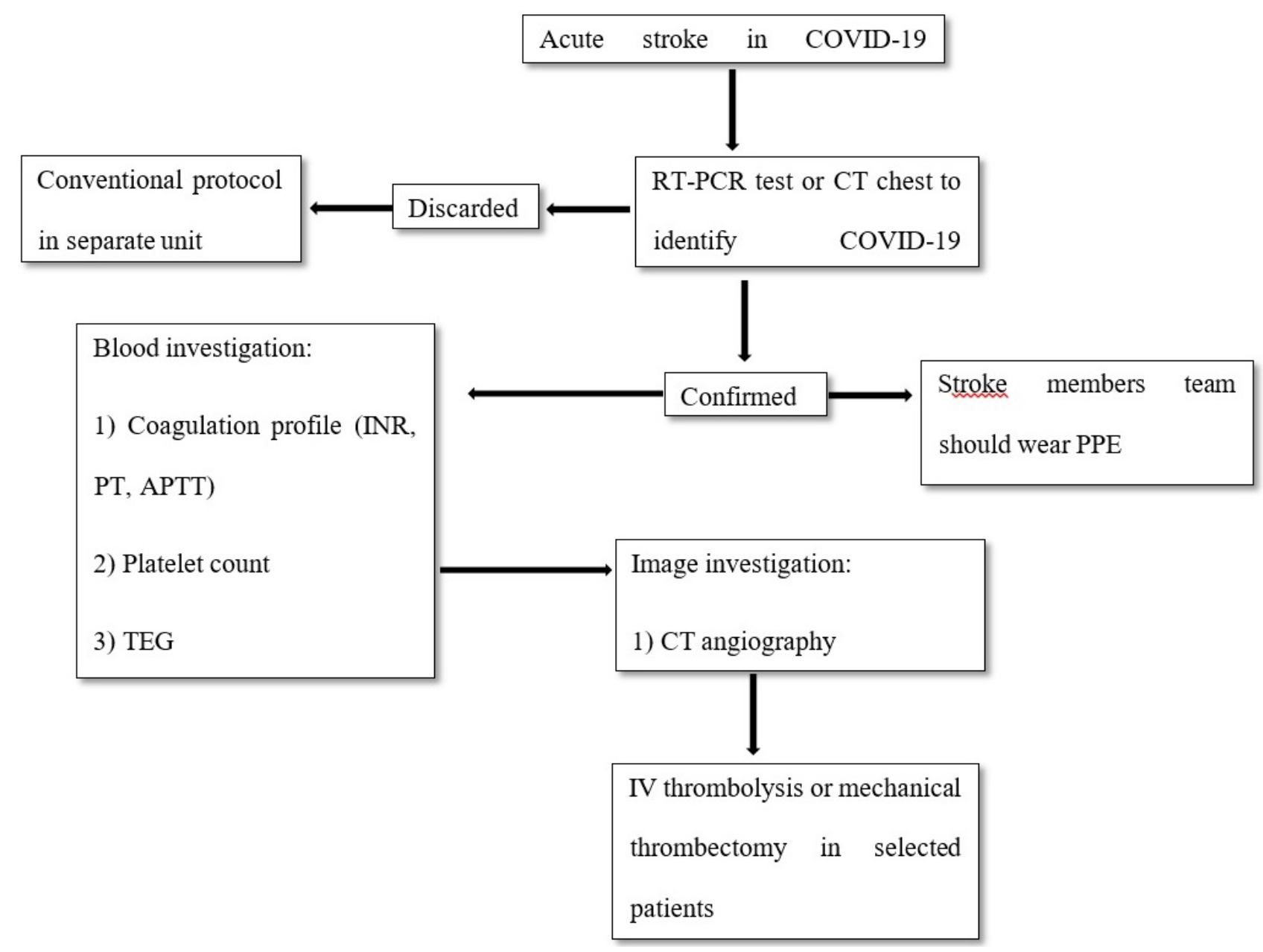

Figure 4: Our algorithm proposed to management COVID-19 patients with ischemic stroke.

RT-PCR: reverse-transcription polymerase chain reaction test; PPE: personal protective equipment; PT: prothrombin time; INR: international normalized ratio; APTT: activated partial thromboplastin time; TEG: thromboelastography; CT: computerized tomography, IV: intravenous.

a higher rate of death or disability and post thrombolytic intracerebral hemorrhages in patients with elevated concentration of C-reactive protein and D-dimers $[25,26]$. Another point is that hepatic dysfunction manifesting as elevation in serum transaminases (elevated prothrombin time (PT), international normalized ratio (INR), activated partial thromboplastin time (APTT), or reduced platelet count) can occur in patients with SARSCoV-2 infection and increase the risk of intracerebral hemorrhages $[25,26]$. Thus, to management of ischemic stroke patients with SARS-CoV-2 infection, a detailed assessment of coagulation profile is crucial to decision regarding IV thrombolysis in these patients. Endovascular thrombectomy should be evaluated according with current guidelines [26].

The era of COVID-19 has brought about significant changes regarding hospital management, at stroke there was a change in the etiology investigation protocol, according to Jin, et al. 2019 Serum D-dimer level is generally increased, being able to reflect in stroke, it is well known that many of these patients may already have other cerebrovascular risk factors, such as hypertension, diabetes mellitus, hyperlipidemia, smoking or a previous history of stroke [27].

If a patient with acute ischemic stroke with a suspected or confirmed diagnosis of COVID-19 is admitted, emergency treatment could be offered, if the D-dimer level is high but additional studies should be performed to affirm this management. In our systematic review with 22 patients included, 21 patients had an ischemic stroke and anticoagulant was instituted in all of the cases, reflecting a better prognosis [6-15].

In the context of the current COVID-19, a necessary point for futures studies is the possibility of coexistence of stroke and refractory hypoxemia, in mechanically ventilated patients. So far too little is known about how to better manage the association of both, especially in large size stroke under risk of elevated intracranial pressure.

The ability to deliver timely and efficacious care for the stroke in itself must be balanced with the risk of potential elevated intracranial pressure that happens as a result of "permissive hypercapnia" during the well-established "protective-lung ventilation strategy" [28]. Rescue approaches such as extracorporeal membrane 
oxygenation (ECMO) coupled with extracorporeal carbon dioxide removal (ECCO2R) may be applied in order to avoid lung disease worsening and protect the brain from herniation simultaneously [29]. Surgical decompressive craniectomy should also be taking into consideration in selected cases either in combination with ECMO/ECCO2R or alone, especially in low resources centers [30].

\section{Prognosis}

The poor prognosis to patients with COVID-19 and stroke not yet are completely elucidated, however, are many possibilities that can suppose this, such as the patients who are in risk factor group develops a virus form more severe. Risk factors are the same to factors to stroke and cardiovascular diseases, so patients with COVID-19 may have cardiovascular manifestations and that cardiovascular morbidities probably result in worst outcomes. Patients with severe infection are more susceptible to develop acute cerebrovascular events than those with less-severe infection [31].

The majority of patients of our revision had previous cardiovascular comorbidities, such as hypertension, cardiac diseases, and diabetes mellitus, therefore they were in fact in the risk group of COVID-19 and this could contribute to a poor prognosis [32].

The studies showed an increased inflammatory response and hypercoagulation disturb state was found in patients that had cerebrovascular events. This information was proved that the risk for worse outcome was higher in patients who are with prolonged prothrombin time, thrombin time, and D-dimer high [16,17,31]. This situation of coagulopathy could turn patients more susceptible to thrombotic events, including stroke. The D-dimer levels are under the limit in only three patients of our revision, therefore being in accordance with the literature. The possibility of COVID-19 can cause clotting in large vessels of patients without risk factors for stroke are suggested by reported 5 cases of large-vessel stroke in young patients under fifty-years-old [31].

In our literature review, including 22 patients (7 women and 15 men), age ranged 33 to 88 -years-old, the outcome of these patients were: 4 died, 2 in severe state and the others was in moderate to good state until the publication of the articles. All of died patients had some risk factors, hypertension, diabetes, smoking, and others cardiac diseases and were severity state. In addition, older patients are vulnerable to poor prognosis [6-15].

Another factor worth mentioning in the analysis of factors predicting the worst outcome for patients with COVID-19 and stroke is hypercapnia caused by mechanical ventilators. The permissive hypercapnia, necessary during protective mechanical ventilation in patients with severe COVID-19, generally an accumulation of $\mathrm{CO}_{2}$, which can determine a state of harmful cerebral hyperemia. These permissive hypercapniais difficult to manage in patients with COVID-19, given that the patient needs to maintain good pulmonary ventilation, although attention is needed to the possible worsening of the neurological condition through this intervention.

When analyzing the characteristics of the patients in this review, it is noticed that the incidence of vascular involvement is of large calibre vessels, which makes the situation even more serious and therefore makes the outcome more unfavourable. Furthermore, it is observed that there are a greater number of cases in ischemic stroke compared to haemorrhagic stroke [10].

\section{Conclusion}

Although it is not yet possible to determine all the precise and specific characteristics of the infection by the coronavirus. There is strong evidence that vascular complications may arise for the most part due to the well-recognized potentially fatal inflammatory storm, which reflects a hyperactivation of inflammatory factors and dysfunction of the coagulation system, especially D-dimer and platelet abnormalities. The prognosis of these patients is therefore linked to the inflammatory process, complicated by severe respiratory conditions, renal, cardiac and hematological disorders.

\section{Limitations}

This review has several limitations. Few studies were available for inclusion. More detailed patient data was unavailable in most studies at the time of analyses. Futures studies are necessary to determinate protocol management and real prognosis in COVID-19 patients.

\section{Author Contributions}

\section{Conceptualization}

Luiz Severo Bem Junior, Andrey Maia Silva Diniz, Luís Felipe Gonçalves de Lima, Júlio Cesár Tavares Marques, Artêmio José Araruna Dias, Pedro Lukas do Rêgo Aquino, Nicollas Nunes Rabelo, Hildo Rocha Cirne de Azevedo Filho.

\section{Project administration}

Luiz Severo Bem Junior, Pedro Lukas do Rêgo Aquino Andrey Maia Silva Diniz, Luís Felipe Gonçalves de Lima, Júlio Cesár Tavares Marques, Artêmio José Araruna Dias.

\section{Formal analysis}

Nicollas Nunes Rabelo, Hildo Rocha Cirne de Azevedo Filho, Luiz Severo Bem Junior, Flávio Monteiro de Oliveira Júnior.

\section{Writing-original draft}

Luiz Severo Bem Junior, Andrey Maia Silva Diniz, Luís Felipe Gonçalves de Lima, Júlio Cesár Tavares Marques, Artêmio José Araruna Dias, Pedro Lukas do Rêgo Aquino.

\section{Writing-review \& editing}

Nicollas Nunes Rabelo, Luiz Severo Bem Junior, Pe- 
dro Lukas do Rêgo Aquino, Hildo Rocha Cirne de Azevedo Filho, Flávio Monteiro de Oliveira Júnior.

\section{Acknowledgment}

We are grateful to the masters of Hospital da Restauração who provided insight and expertise that greatly assisted the research, and actively stimulated the search for answers.

\section{Conflicts of Interest}

The authors have no potential conflicts of interest to disclose.

\section{Financial Disclosure or Funding}

None to declare.

\section{Data Availability}

The authors declare that data supporting the findings of this study are available within the article.

\section{Ethical approval}

Approval was not required.

\section{References}

1. WG Glass, K Subbarao, B Murphy, PM Murphy (2004) Mechanisms of Host Defense following Severe Acute Respiratory Syndrome-Coronavirus (SARS-CoV) Pulmonary Infection of Mice. J Immunol 173: 4030-4039.

2. C Huang, Y Wang, X Li, L Ren, J Zhao, et al. (2020) Clinical features of patients infected with 2019 novel coronavirus in Wuhan, China. Lancet 395: 497-506.

3. Zhu N, Zhang D, Wang W, Li X, Yang B, et al. (2020) China Novel Coronavirus Investigating and Research Team. A novel coronavirus from patients with pneumonia in China. N Engl J Med 382: 727-733.

4. Bem LS, Aquino P, Rabelo N, Aquino M, Silva A, et al (2020) SARS-CoV-2 and nervous system - Neurological manifestations in patients with COVID-19: A systematic review. J Neurol Research 10: 113-121.

5. Mao L, Jin H, Wang M, Hu Y, Chen S, et al. (2020) Neurologic Manifestations of Hospitalized Patients With Coronavirus Disease 2019 in Wuhan, China. JAMA Neurol 77: 683-690.

6. Avula A, Nalleballe K, Narula N, Sapozhnikov S, Dandu V, et al. (2020) COVID-19 presenting as stroke. Brain Behav Immun 87: 115-119.

7. Al Saiegh F, Ghosh R, Leibold A, Avery MB, Schmidt RF, et al. (2020) Status of SARS-CoV-2 in cerebrospinal fluid of patients with COVID-19 and stroke. J Neurol Neurosurg Psychiatry 91: 846-848.

8. Beyrouti R, Adams ME, Benjamin L, Cohen H, Farmer SF, et al. (2020) Characteristics of ischaemic stroke associated with COVID-19. J Neurol Neurosurg Psychiatry 91: 889891.

9. González-Pinto T, Luna-Rodríguez A, Moreno-Estébanez A, Agirre-Beitia G, Rodríguez-Antigüedad A, et al. (2020) Emergency room neurology in times of COVID-19: malignant ischaemic stroke and SARS-CoV-2 infection. Eur J Neurol.

10. Oxley TJ, Mocco J, Majidi S, Kellner CP, Shoirah H, et al.
(2020) Large-Vessel Stroke as a Presenting Feature of Covid-19 in the Young. N Engl J Med 382: e60.

11. P Moshayedi, TE Ryan, LLP Mejia, M Nour, DS Liebeskind (2020) Triage of Acute Ischemic Stroke in Confirmed COVID-19: Large Vessel Occlusion Associated With Coronavirus Infection. Front Neurol 11: 353.

12. Hughes C, Nichols T, Pike M, Subbe C, Elghenzai S (2020) Cerebral Venous Sinus Thrombosis as a Presentation of COVID-19. Eur J Case Rep Intern Med 7: 001691.

13. Viguier A, Delamarre L, Duplantier J, Olivot JM, Bonneville F (2020) Acute ischemic stroke complicating common carotid artery thrombosis during a severe COVID-19 infection. J Neuroradiol 47: 393-394.

14. Tunç A, Ünlübaş $Y$, Alemdar M, Akyüz E (2020) Coexistence of COVID-19 and acute ischemic stroke report of four. J Clin Neurosci 77: 227-229.

15. Goldberg MF, Cerejo R, Tayal AH (2020) Cerebrovascular Disease in COVID-19. AJNR Am J Neuroradiol.

16. Tang N, Li D, Wang X, Sun Z (2020) Abnormal coagulation parameters are associated with poor prognosis in patients with novel coronavirus pneumonia. J Thromb Haemost 18: 844-847.

17. Guan WJ, Ni ZY, Hu Y, Liang WH, Ou CQ, et al. (2020) Clinical Characteristics of Coronavirus Disease 2019 in China. N Engl J Med 382: 1708-1720.

18. Spiezia L, Boscolo A, Poletto F, Cerruti L, Tiberio I, et al. (2020) COVID-19-Related Severe Hypercoagulability in Patients Admitted to Intensive Care Unit for Acute Respiratory Failure. Thromb Haemost 120: 998-1000.

19. Chousterman BG, Swirski FK, Weber GF (2017) Cytokine storm and sepsis disease pathogenesis. Semin Immunopathol 39: 517-528.

20. Meduri GU, Kohler G, Headley S, Tolley E, Stentz F, et al. (1995) Inflammatory cytokines in the BAL of patients with ARDS. Persistent elevation over time predicts poor outcome. Chest 108: 1303-1314.

21. Huang X, Wei F, Hu L, Wen L, Chen K (2020) Epidemiology and Clinical Characteristics of COVID-19. Arch Iran Med 23: 268-271.

22. McGonagle D, Sharif K, O'Regan A, Bridgewood C (2020) The Role of Cytokines including Interleukin-6 in COVID-19 induced Pneumonia and Macrophage Activation Syndrome-Like Disease. Autoimmun Rev 19: 102537.

23. Zubair A, McAlpine L, Gardin T, Farhadian S, Kuruvilla D, et al. (2020) Neuropathogenesis and Neurologic Manifestations of the Coronaviruses in the Age of Coronavirus Disease 2019. JAMA Neurol.

24. Divani AA, Andalib S, Di Napoli M, Lattanzi S, Hussain MS, et al. (2020) Coronavirus Disease 2019 and Stroke: Clinical Manifestations and Pathophysiological Insights. J Stroke Cerebrovasc Dis 29: 104941.

25. Dafer RM, Osteraas ND, Biller J (2020) Acute Stroke Care in the Coronavirus Disease 2019 Pandemic. J Stroke Cerebrovasc Dis 29: 104881.

26. Qureshi Al, Abd-Allah F, Al-Senani F, Aytac E, Borhani-Haghighi A, et al. (2020) Management of acute ischemic stroke in patients with COVID-19 infection: Report of an international panel. Int J Stroke 15: 540-554.

27. Jin H, Hong C, Chen S, Zhou Y, Wang Y, et al. (2020) Consensus for prevention and management of coronavirus disease 2019 (COVID-19) for neurologists. Stroke Vasc Neurol 5: 146-151. 
28. Rotman V, Carvalho AR, Rodrigues RS, Medeiros DM, Pinto EC, et al. (2016) Effects of the open lung concept following ARDSnet ventilation in patients with early ARDS. BMC Anesthesiol 16: 40.

29. Combes A, Slutsky AS, Brodie D, Demoule A, Lavoué S, et al. (2018) ECMO for Severe Acute Respiratory Distress Syndrome. N Engl J Med 379: 1091-1092.

30. Sahuquillo J, Martínez-Ricarte F, Poca MA (2013) Decompressive craniectomy in traumatic brain injury after the DECRA trial. Where do we stand? Curr Opin Crit Care 19: 101-106.
31. Pranata R, Huang I, Lim A, Wahjoepramono E, July J (2020) Impact of Cerebrovascular and Cardiovascular Diseases on Mortality and Severity of COVID-19-Systematic Review, Meta-analysis, and Meta-regression. Journal of Stroke Cerebrovascular Diseases 29: 104949.

32. Aggarwal G, Lippi G, Michael Henry B (2020) Cerebrovascular disease is associated with an increased disease severity in patients with Coronavirus Disease 2019 (COVID-19): A pooled analysis of published literature. International Journal of Stroke 15: 385-389. 